\title{
From blood coagulation to innate and adaptive immunity: the role of platelets in the physiology and pathology of autoimmune disorders
}

\author{
Zuzanna Małgorzata Łukasik ${ }^{1}$ (D) Marcin Makowski ${ }^{2}$ D $\cdot$ Joanna Samanta Makowska $^{1}$ (D)
}

Received: 16 January 2018 / Accepted: 22 February 2018 / Published online: 28 February 2018

(c) The Author(s) 2018. This article is an open access publication

\begin{abstract}
Thrombosis and cardiovascular complications are common manifestations of a variety of pathological conditions, including infections and chronic inflammatory diseases. Hence, there is great interest in determining the hitherto unforeseen immune role of the main blood coagulation executor-the platelet. Platelets store and release a plethora of immunoactive molecules, generate microparticles, and interact with cells classically belonging to the immune system. The observed effects of platelet involvement in immune processes, especially in autoimmune diseases, are conflicting-from inciting inflammation to mediating its resolution. An in-depth understanding of the role of platelets in inflammation and immunity could open new therapeutic pathways for patients with autoimmune disorders. This review aims to summarize the current knowledge on the role of platelets in the patomechanisms of autoimmune disorders and suggests directions for future research.
\end{abstract}

Keywords Blood platelets $\cdot$ Autoimmunity $\cdot$ Rheumatoid arthritis $\cdot$ Systemic lupus erythematosus $\cdot$ Systemic sclerosis $\cdot$ Anti-phospholipid antibody syndrome

\section{Introduction}

Platelets are anucleate derivatives of the megakaryocytic cytoplasm. They were long perceived as participating solely in haemostasis and thrombosis [1]. As many as 100 billions of these discoid, cell elements with a relatively short life span need to be produced daily to maintain the average platelet count of $2-3 \times 10^{8}$ per blood $\mathrm{ml}$ [2]. Platelets are equipped with megakaryocyte clusters of differentiation, various surface receptors and glycoproteins, cytoskeletal elements, granules, and a smooth endoplasmic reticulum tubular system [3]. These properties, together with platelets' ubiquitous presence, make them perfect candidates for immune cells. Currently, platelets are gaining increasing

Joanna Samanta Makowska

joanna.makowska@umed.lodz.pl

Zuzanna Małgorzata Łukasik

zuzanna.lukasik@stud.umed.lodz.pl

Marcin Makowski

drmarmak@gmail.com

1 Department of Rheumatology, Medical University of Lodz, Ul. Pieniny 30, 92-115 Łódź, Poland

2 Department of Intensive Care, Cardiology, Medical University of Lodz, Łódź, Poland recognition as active regulators of innate and adaptive immunity [4]. With chronic systemic inflammation being regarded as the axis of the pathogenesis of autoimmune disorders (AD) and elevated risk of cardiovascular events among $\mathrm{AD}$ patients, research into the contribution of platelets in the pathogenesis and course of these diseases is particularly attractive $[5,6]$. The aim of this comprehensive narrative review is to present the most current evidence for platelet involvement as immune cells in the course of systemic $\mathrm{AD}$, discuss usefulness of platelet indices in clinical practice, and point towards future areas of research.

\section{Literature search and review methodology}

Literature searches were conducted between April and September 2017 using MEDLINE database, comprised of published data only and included both existing review articles and original studies in English. The search used the following search string: 'blood platelets' AND 'autoimmunity' OR 'autoimmune diseases' OR 'immune'. Preference was given to the sources published since 2002. Articles and abstracts were screened for relevance and only those covering systemic autoimmune disorders were included. References in 
the articles meeting inclusion criteria were examined as well.

\section{Platelets as immune cells}

\section{The role of platelets in haemostasis}

Blood flow forces platelets along the vessel wall, where they act as sentinels of vascular integrity. Disruption of the vessel wall results in exposure of extracellular matrix components such as subendothelial collagen, vitronectin, fibronectin, or laminin. Platelet glycoprotein complex GP Ib/IX/V and various surface integrins work as initial adhesive receptors and enable platelet binding at the site of an endothelial lesion. This binding initiates the adhesion, activation, and accumulation of platelets, which together is regarded as the first step of haemostasis. Platelets also contribute to the second step: the blood coagulation pathway [7]. Upon platelet activation, changes in the composition of the phospholipid bilayer of the plasma membrane occur. Unsaturated acyl chains are exposed on the outer leaflet. The platelet cell membrane bears a nett negative charge, and this accelerates the activation of factor $\mathrm{X}$ and prothrombin, by providing sites for the assembly of enzyme substrate complexes. Changes in the platelet cell membrane lead also to the generation of platelet-derived microparticles and a body of evidence points towards their role as initiators of thrombosis via the tissue factor pathway [8]. In mouse models, platelets were shown to become hyperactive after induction by microparticles derived from damaged endothelial cells [9]. This represents a positive feedback loop further enhancing the already increased coagulant activity of the platelets and putting them in the centre of thrombotic events.

However, a variety of pathological conditions, which are not strictly associated with vascular damage, manifest as a tendency towards thrombosis or as excessive bleeding [10]. This includes conditions as diverse as bacterial and parasite infections, malignant neoplasms, and autoimmune disorders. This observation has inspired a new route of research, investigating whether platelets should be regarded as immune cells [11].

\section{Platelets' surface receptors}

An examination of platelet surface reveals it to be bristling with receptors. Quiescent platelets bear receptors intended to efficiently monitor vascular integrity. Upon activation, platelets upregulate other types of receptors, and shared with classic constituents of the immune system [12]. For example, toll-like receptors (TLRs) enable platelets to recognize pathogen- and damage-associated molecular patterns and immune complexes. TLRs also enable numerous interactions between platelets and leukocytes [12]. Ligand binging results in the initiation of intracellular signalling that converges upon significant cytoskeletal changes, involving the formation of pseudopodia and the opening of the canalicular system. These changes provide small-sized cells with a greater surface area, enable release of stored molecules, generation of microvesicles and microparticles and, most importantly, rearrangement of surface proteins [13]. Siglec receptors are involved in platelet apoptosis and down-regulation of the inflammatory response [14-20].

Two of the platelet surface proteins should be discussed more thoroughly due to their role in predicting cardiovascular complications. Glycoprotein integrin $\alpha \mathrm{IIb} \beta 3$ (GPIIb/IIIa) is the most abundant platelet receptor with 50-80 thousand copies on the cell surface and an additional pool stored in the $\alpha$ granules [19]. An increase in the intracellular level of calcium leads to conformational changes of the molecule and subunit association, which only jointly form a functional complex. The surface density of the complex increases as well. This enables the cross-linking of plasma fibrinogen or von Willebrand Factor (vWF) and consequent platelet aggregation and intracellular communication, necessary for the recruitment of additional platelets to the site of vascular injury and thrombus formation. Platelet glycoprotein $\mathrm{Ib}$ alpha chain (GPIba), a component of the Glycoprotein Ib-IX$\mathrm{V}$ receptor complex, is also up-regulated; it facilitates further platelet adhesion to the endothelium and supports intercellular signalling, also with neutrophils [21, 22]. P-selectin is present only on activated platelets (but also expressed on endothelial cells) and, therefore, serves as a marker of platelet activation. The counter ligand for P-selectin (PSGL-1) is a homodimeric mucin expressed on most leukocytes, but especially abundant on monocytes and neutrophils. The interaction is crucial for adaptive immunity as it induces leukocyte activation, integrin Mac-1 surface clustering (which enables other adhesion interactions between platelets and leukocytes), and neutrophil transendothelial migration. In addition, $\mathrm{P}$-selectin enables the binding of complement $\mathrm{C} 3 \mathrm{~b}$.

\section{Platelets' granules}

Together with the changes occurring in the composition and quantity of their surface proteins, activated platelets also release the contents of their granules. Platelets contain almost 4000 unique proteins, more than 300 of which have been detected in platelet releasates. Many of them are megakaryocyte-preformed and stored in one of the three types of granules: dense granules, alpha granules, or lysosomes. Dense granules contain mostly small molecules, such as adenosine diphosphate (ADP), ionised calcium, or serotonin (5-HT). Lysosomes encapsulate a variety of hydrolytic enzymes. Alpha granules contain a plethora of cytokines, whose immune functions range from unquestionably 
pro-inflammatory to serving as indispensable anti-inflammatory agents [23]. Table 1 presents some of the platelet releasates stored in alpha granules. It is unlikely that such a multitude of bioactive substances with contradictory effects is secreted randomly: it is currently believed that platelets are capable of stimulus-dependent packaging and release of granule content.

A secreted molecule that deserves particular attention in the context of autoimmunity is CD40L (also known as CD154). It is a membrane glycoprotein expressed by activated platelets [32]. Over a period of minutes to hours, surface-expressed CD40L is cleaved and released in soluble form (sCD40L). It is estimated that over $95 \%$ of $\mathrm{SCD} 40 \mathrm{~L}$ is of platelet origin [33]. Its binding to CD40 on endothelial cells triggers an inflammatory response, such as the release of leukocyte-attracting mediators [34]. It is involved in regulating T-cell function, the activation of dendritic cells, and the regulation of T-dependent antibody isotype switching; it also provides a novel mechanism for platelet autoactivation and the formation of homotypic platelet aggregates [35].

\section{Protein production de novo}

However, platelets are not just storage vesicles that degranulate upon activation. Recent studies revealed that the molecules present in platelets may come from sources other than megakaryocytes. They can be absorbed from the plasma or generated de novo [36]. Surprisingly, these anucleate cytoplasts possess functional spliceosome and transcriptome, accompanied by a range of ribonucleic acids and all the molecular machinery needed to autonomously produce proteins. This was a fascinating discovery, since spliceosome has never been described outside the nuclear boundaries [37]. Spliceosome allows platelets to synthesize proteins de novo in a stimulus-tailored manner. The process was well depicted for a potent pro-inflammatory factor interleukin $1-\beta$ (IL1- $\beta$ ) [38]. mRNA for IL1- $\beta$ is one of the constitutive transcripts in unstimulated platelets [39]. It is located in the polysomes of resting and activated platelets. Accumulation of pro-IL1- $\beta$ is sustained over hours after platelet activation and followed by processing the precursor into its mature, active form [37]. Integrated post-transcriptional control mechanisms regulate the initiation and resolution of inflammation and give explanation to the role of platelets in immune response and tissue injury [40].

\section{Platelet microRNA}

A fascinating discovery revealed that platelets possess significant amounts of small non-coding RNA, of which around $80 \%$ accounts for microRNA (miRNA) [41]. miRNA molecules are thought to post-transcriptionally regulate the expression of over $60 \%$ of human genes. The miRNA present in platelets not only influences the functioning of the platelets themselves but also other immune cells, and can both restrain and promote autoimmunity [42]. For instance, miR-146a contributes to controlling the overproduction of cytokines, such as TNF- $\alpha$, functions as a negative feedback control of innate immunity in TLR signalling and is critical for the suppressor functions of regulatory $\mathrm{T}$ lymphocytes. miR-155 promotes the development of pro-inflammatory Th17 and Th1 cell subsets [42].

\section{Platelet-derived microparticles}

Another sign of platelet activation is the generation of microparticles. A range of cells release these small membrane vesicles in both quiescent state and upon activation, but it is platelets that account for over $90 \%$ of plasma microparticles found in healthy individuals $[9,43]$. Thanks to their size, platelet-derived microparticles (PMP) can easily infiltrate tissues and work as highly efficient carriers of bioactive molecules $[44,45]$. They perform this task instead of activated platelets, which acquire binding properties that make it difficult for them to travel through the circulatory system. Microparticles may affect target cells by stimulating them directly via surface-expressed ligands or by transferring surface receptors, which has been reported for both physiological and malignant cells [46]. They modify recipient cell function also by the delivery of cytoplasmic proteins and miRNA [45, 47-49]. They have been shown to increase the expression of adhesion molecules on endothelial and immune cells, enhance cytokine release, and consequently induce angiogenesis [50]. Moreover, PMPs are highly procoagulant and play important role in haemostasis and thrombosis $[8,51]$. PMPs provide a surface for complement deposition and participate in complement activation $[52,53]$. The fact that circulatory levels of PMPs are significantly elevated in infections, $\mathrm{AD}$, cardiovascular disorders and other pathologic conditions points to their possible role as actual effectors of platelet immune functions [5].

\section{Platelets in cell-cell interactions}

The up-regulation of adhesion molecules and soluble releasates, coherently functioning together, enables platelet-leukocyte interactions [54].

\section{Platelet-neutrophils}

Activated platelets have been shown to adhere to circulating neutrophils and via the release of pro-inflammatory IL $\beta 1$, HMGB 1, PDGF recruit them to the site of vascular injury [55]. P-selectin expressed on the surface of both activated platelets and endothelial cells promotes the generation of 
Table 1 Selected platelet releasates stored in alpha granules

\begin{tabular}{|c|c|c|}
\hline Molecule classification & Molecule & Immune function \\
\hline \multirow[t]{6}{*}{ chemokines } & $\beta$-thromboglobulin & Chemoattractant and activator for neutrophils \\
\hline & CXCL4, PF4 & $\begin{array}{l}\text { Most abundant cytokine in alpha granules; involved in platelet-mediated killing of } \\
\text { Plasmodium falciparum; necessary for platelet-induced NETosis; prevents neutrophil } \\
\text { apoptosis, activation and adhesion of neutrophils to endothelial cells, phagocytosis and } \\
\text { respiratory burst in monocytes, chemotaxis of T lymphocytes; PF4 in the presence of } \\
\text { TNF- } \alpha \text { induces exocytosis and firm neutrophil interaction with endothelium thereby } \\
\text { enhancing inflammation in the lesion; modulates TNF expression; is a potent anti-angi- } \\
\text { ogenic factor by preventing binding of VEGF to endothelial cells }\end{array}$ \\
\hline & PPBL, CXCL7 & $\begin{array}{l}\text { As a result of proteolytic modifications is transformed into connective tissue- and } \\
\text { neutrophil-activating peptide, stimulates transendothelial migration of neutrophils }\end{array}$ \\
\hline & RANTES, CCL5 & Arrests monocyte infiltration of the endothelium \\
\hline & CCL3, MIP1-alpha & $\begin{array}{l}\text { Involved in host defence, targets and induces chemotaxis in multiple immune cells: } \\
\text { monocytes, eosinophils, basophils, NK cells, CD8 + T lymphocytes, and DC subsets; } \\
\text { significant for development and stabilization of atherosclerotic lesions; induces hista- } \\
\text { mine release from basophils }\end{array}$ \\
\hline & CCL-7 & $\begin{array}{l}\text { Targets and induces chemotaxis in multiple immune cells: monocytes, eosinophils, baso- } \\
\text { phils, NK cells, CD8 + T lymphocytes and DC subsets }\end{array}$ \\
\hline \multirow[t]{5}{*}{ Growth factors } & VEGF & Involved in physiological angiogenesis and wound healing \\
\hline & PDGF & $\begin{array}{l}\text { Involved in angiogenesis, is potent mitogen for mesenchymal cells including fibroblasts, } \\
\text { smooth muscle cells, and glial cells } \\
\text { Chemoattracts and activates neutrophils and monocytes; modulates T-cell functions }\end{array}$ \\
\hline & TGF $\beta$ & $\begin{array}{l}\text { Essential permissive factor for metastasis, specifically in epithelial-mesenchymal-like } \\
\text { transition }\end{array}$ \\
\hline & EGF & Monocyte chemoattractant \\
\hline & Angiopoietin-1 & Preserves vascular integrity at site of inflammation \\
\hline \multirow[t]{5}{*}{ Cytokines } & IL-1 $\beta$ & Activates endothelial and smooth muscle cells; augments neutrophil adhesiveness \\
\hline & IL-7 & Involved in apoptosis resistance, stimulates pro-inflammatory cytokine production \\
\hline & IL-8 & \\
\hline & HMBG & Activates neutrophils: pericellular granules distribution and release of NETs \\
\hline & MIP-1- $\alpha$ & See: chemokines \\
\hline \multirow[t]{2}{*}{ Proteolytic enzymes } & Metalloproteinase Inhibitors & \\
\hline & $\begin{array}{l}\text { Protease inhibitors } \\
\text { Platelet inhibitor of FXI } \\
\text { C1 inhibitor }\end{array}$ & Attenuates inflammation and promotes resolution, involved in clot dissolution \\
\hline \multirow[t]{9}{*}{ Other } & CD40L, CD154 & $\begin{array}{l}\text { Induces chemokine secretion and up-regulation of adhesion molecules on endothelial } \\
\text { cells; involved in maturation of immunoglobulin affinity and isotype switch in B cells; } \\
\text { involved in DC maturation; augmentation of T-cell responses }\end{array}$ \\
\hline & PAF & $\begin{array}{l}\text { Pro-inflammatory lipid mediator, involved in host defence; activates monocytes, neutro- } \\
\text { phils and promotes formation of heterotypic platelet aggregates }\end{array}$ \\
\hline & Histamine & Pleiotropic immune modulator \\
\hline & Fibronectin & Involved in host defence \\
\hline & Vitronectin & Matrix binding protein \\
\hline & Thrombospondin & Adhesion molecule involved in angiogenesis regulation \\
\hline & Fibrinogen & Positive loop of platelet activation \\
\hline & vWF & Positive loop of platelet activation \\
\hline & HRG & $\begin{array}{l}\text { Antimicrobial protein; supresses T-cell activity suppressor, macrophage phagocytosis and } \\
\text { formation of immune complexes }\end{array}$ \\
\hline
\end{tabular}

Selected molecules stored in platelet alpha granules [6, 21, 23-31]

$C X C L 4, P F 4$ platelet factor 4, NET neutrophil-extracellular traps, TNF tumor necrosis factor, VEGF vascular Endothelial Growth Factor, $P P B L$, CXCL7 pro-Platelet Basic Protein, RANTES, CCL5 Chemokine C-C motif Ligand 5, regulated on activation, normal T-cell expressed and secreted CCL5, CCL3, MIP1-alpha Chemokine C-C motif Ligand 3, Macrophage Inflammatory Protein 1-alpha, $N K$ natural killer, DC Dendritic Cells, $C C L-7$ Chemokine Ligand 7, monocyte-chemotactic protein 3, PDGF Platelet-derived Growth Factor, TGF $\beta$ transforming growth factor beta, $E G F$ epidermal growth factor, $H M B G$ high mobility group box-1, $C D 40 L, C D 154$ CD 40 Ligand, $P A F$ platelet activating factor, $v W F$ von Willebrand Factor, $H R G$ Histidine-rich glycoprotein 
reactive oxygen species, activation of $\beta 2$ integrins and leukocyte tissue factor, release of pentraxin 3, and proteolytic enzymes [33]. Platelets have an important effect on neutrophils: the induce neutrophil-extracellular trap (NET) formation [56]. This is a form of cell autophagy, distinctive from apoptosis, which is based on the fusion of primary granules with nuclear membrane. It results in the destruction of neutrophil genetic material and its subsequent expulsion to the extracellular environment, where the NET engulfs pathogens. NETs reversely activate platelets, what may lead to a vicious loop of NET formation and platelet activation [57], resulting in tissue injury, prothrombotic phenotype, and propagation of autoimmunity [58]. Interactions with neutrophils also enable platelet extravasation and the targeting of other tissues, as reported in several autoimmune disorders [59]. Platelets support reactive oxygen species generation by monocytes and promote neutrophil oxidative burst and prothrombotic phenotype of monocytes [55, 60]. At the same time, platelet-neutrophil conglomerates enable transcellular synthesis of bioactive lipid compounds, including molecules required for inflammation resolution such as lipoxins, maresins, and resolvins [61, Fig. 1].

\section{Platelet-lymphocytes}

In healthy subjects, about $3 \%$ of circulating lymphocytes is bound to platelets. This number increases significantly upon platelet activation and homeostasis deregulation $[62,63]$. The proportion varies between lymphocyte subpopulations and depends on the level of platelet activation and the form of stimulus [64]. Larger, activated lymphocytes are more prone to bind to platelets. Surface proteins P-selectin, GPIIb/ IIIa, CD40, and CD11b all contribute to the interaction. The presence of the scavenger receptor CD36 on lymphocytes was recognized as proof of interaction with platelets [65].

The co-culturing of autologous platelets and CD4 + T cells enhanced the production of IL-10 and cytokines characteristic for Th1 and Th17 cells: IFN $\gamma$, IL-17. Moreover, the $\mathrm{T}$ cells were more prone to differentiate towards types Th1 and Th17, which are associated with autoimmunity [66, 67]. IL-17 is an independent predictor of vascular function in rheumatic diseases [68]. At the same time, platelet binding reduces the capability of lymphocytes to proliferate and produce Th1/Th17 cytokines [69]. This suggests that platelets may have a different effect on leukocytes depending on the stage of inflammatory response. Platelets alter
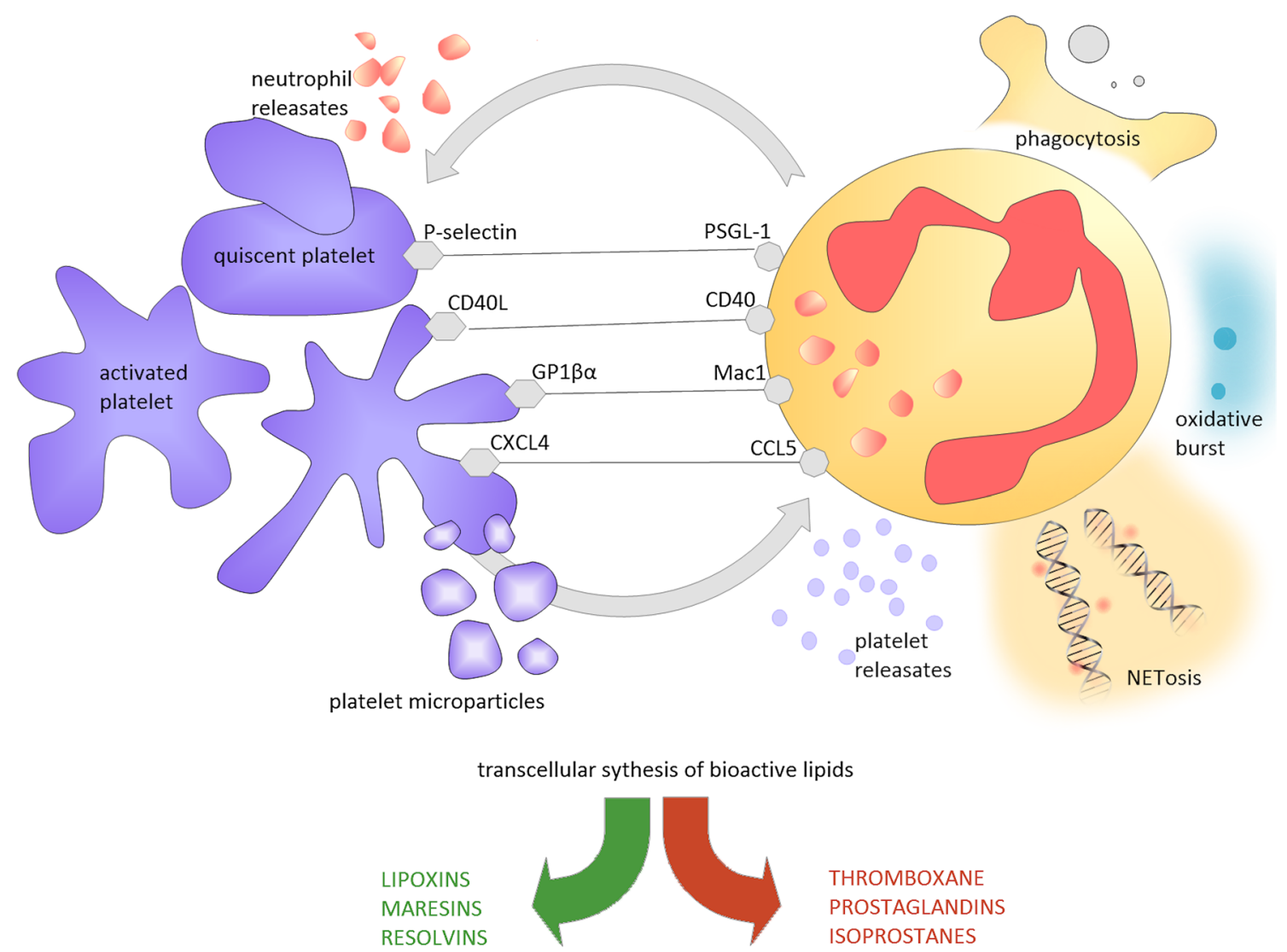

Fig. 1 Platelet-neutrophil interactions. The figure presents interactions between platelets and neutrophils 
immunoglobulin production also through direct contact with lymphocytes B. They are capable of delivering CD40L signalling that is crucial to immunoglobulin affinity maturation and isotype switching and T-cell-dependent humoral immune response [70]. The co-incubation of differentiated $B$ cells with activated platelets was associated with increased in vitro production of $\mathrm{IgG1}$, IgG2, and IgG3 [70]. Moreover, platelets were demonstrated to directly activate naïve $\mathrm{T}$ cells by presenting antigens in the context of MHCI and delivering co-stimulatory molecules [71].

\section{Transcellular synthesis of bioactive lipid mediators}

Adhesive platelet-heterotypic cell interactions enable the process of transcellular production of bioactive lipids that act as autacoids [72]. Eicosanoids have gained recognition as regulators of two active, contrary processes: the evolution and resolution of inflammation. The fact that these molecules are unstable and highly bioactive first implied that they must be independently synthesized by different cells. However, only a few cell types are capable of performing the complete biosynthetic process of the limited range of eicosanoids due to lack of key enzymes. Cells must, therefore, share their enzymes and coordinate efforts to produce bioactive lipid compounds in the process of transcellular synthesis [73]. The omnipresence of platelets in blood makes them perfect candidates for this phenomenon. Indeed, platelets are unique cells equipped with a range of enzymes including several forms of phospholipase A2 (PLA2) and 12-lipooxygenase (12-LOX) [9].

Platelets participate in both intensifying inflammation and in its resolution. Upon activation, platelet membrane phospholipid bilayer composition undergoes changes, and substrates are made available for bioactive species production [74]. Platelets can autonomously generate some eicosanoids: thromboxane A2 (TXA2), 12-hydroxyeicosatetraenoic acid (12-HETE), 12-hydroxyheptadecatrienoic acid (12-HHT), prostaglandin E2 (PGE2), prostaglandin D2 (PGD2), and isoprostanes. The molecules have generally proaggregatory and pro-inflammatory properties. Moreover, platelet-neutrophil transcellular biosynthesis of leukotrienes accounts for significant physiological changes associated with an ongoing inflammatory response [75]. Platelets may deliver both arachidonic acid (AA) and leukotriene A4 (LTA4) to neutrophils, as well as other leucocytes and endothelial cells. Prostaglandins have dual role: they initiate inflammatory responses [76], but also induce the transcriptional regulation of neutrophil 15-lipooxygenase (15-LOX). This is the first step in the class switch of lipid mediators $[61,77]$.

The resolution of inflammation is an active process initiated by a switch in the class of synthesized mediators, from the aforementioned thromboxanes, leukotrienes, and prostaglandins to endogenous pro-resolution lipid mediators: resolvins, protectins, maresins, and lipoxins. Lipoxins may be AA derivatives, but others are derived solely from dietary polyunsaturated fatty acids (PUFAs) [77]. Lipoxins themselves are produced in only three pathways, one of which is performed by platelet-neutrophil aggregates, whereby the neutrophils deliver LTA4, which is consequently transformed into lipoxin B4 (LB4) with platelet 12-LOX. LB4 has potent anti-inflammatory properties: it counter-regulates LT and cytokine production (including TNF), decreases vascular permeability, inhibits neutrophil tissue infiltration, and regulates platelet-neutrophil interactions [61]. These are also affected by ASA-triggered lipoxin (ATL), a molecule synthesized in a pathway enabled by acetylation of cyclooxygenase 2 (COX-2) enzymes [78]. Platelets deliver prostaglandin $\mathrm{H} 2$ ( $\mathrm{PGH} 2$ ), a COX product, to endothelial cells which transform it into prostacyclin (PGI2). PGI2 works as a counterweight to TXA2. An imbalance between these two molecules may result in the formation of a prothrombotic phenotype [9].

Along with macrophages, monocytes and neutrophils, platelets transform omega-3 essential PUFAs to resolvins, protectins, and maresins. These molecules promote wound healing, deactivate leukotrienes, and attenuate nuclear factor NFkB [79]. They also intensify phagocytosis of apoptotic cells and phagocyte removal via lymphatic vessels. Their anti-inflammatory effect on platelets is based on reducing ADP-dependent platelet aggregation and redirection molecule production onto growth factors and pro-resolving mediators [77]. Platelet-neutrophil aggregates form maresin 1 , a compound that is organ-protective [80], and influences blood cells by promoting a pro-resolving platelet phenotype and reposing macrophage functions [81, 82].

\section{Evidence for platelet contribution in autoimmune disorders}

Rheumatoid arthritis (RA) is probably the most common connective tissue disease, affecting almost $1 \%$ of global population. Cardiovascular disease is the leading cause of death in RA patients [83]. According to European League Against Rheumatism (EULAR) recommendations, the result of traditional cardiovascular risk assessment equations should be multiplied by 1.5 for RA patients [84].

Multiple evidence point towards increased platelet activation in RA patients. Many of them have an increased platelet count. It can be explained by reduced platelet survival and accelerated turnover rate [85]. Intensified platelet production results in higher percentage of young platelets in circulation. Younger platelets are characterized by enlarged size and higher reactivity. Increased amount of soluble platelet releasates, such as: P-selectin, beta-thromboglobulin, or PF4, are found in the serum of RA patients. They were also found to 
have a higher number of circulating PMPs [86]. Increased platelet activation, assessed with these indicators, correlates positively with disease severity [87-93]. In mouse, model of RA platelet depletion leads to inflammation alleviation [94].

In the serum of RA patients, immune complex and autoantibody characteristics for RA can activate platelets [95]. This includes anti-citrullinated protein antibodies (ACPA) and rheumatoid factor (RF). ACPA-IgE immune complexes may activate platelets via FccRIIA and FceRIahigh- and low-affinity receptor (FceRII/CD23) for IgE, and low-affinity immunoglobulin $\mathrm{G}$ (IgG) receptor (Fc $\gamma$ RIIa) [17]. The percentage of ACPA to total IgG shows a positive correlation with platelet activation and disease activity [95]. The presence of these antibodies [96, 97] was proposed as a novel risk factor of cardiovascular events $[98,99]$ and atherosclerotic plaque instability $[15,100,101]$.

In vessels as well as in RA-inflamed joints, the exposure to the extracellular matrix stimulates platelets. Platelets bind to exposed collagen via glycoprotein VI membrane receptor (GPVI) and this interaction provokes generation of PMP abundant in IL-1 [102]. Elevated PMP counts were found not only in plasma, but also in the synovial fluid of RA patients. In fact, PMP concentration in synovial fluids was significantly higher than in blood, suggesting that increased PMP generation occurs locally [102].

IL-1, so abundant in synovial fluid PMP, is the key molecule for intercommunication between platelets and fibroblast-like synoviocytes (FLS) [103]. Activated FLS are regarded as key effectors of cartilage destruction [104] and defective angiogenesis in RA [50]. In comparison with healthy subjects, RA patients' FLS express altered levels of cytokines, chemokines, adhesion molecules, and matrix metalloproteinases, and they also become resistant to apoptosis. Their interaction with platelets expands beyond the soluble cytokines. In the process of transcellular biosynthesis, platelets and FLS produce prostaglandin I2 (PGI2). PMP stimulate up-regulation of eicosanoid synthesis enzymes: COX-2, microsomal prostaglandin E synthase 1 (mPGES1), and PGE2 [105]. PGE2 itself enhances the expression of membrane-bound mPGE. Independently of PMP generation, and platelet-fibroblast-like synoviocytes aggregate synthesize prostacyclin. The synthesis occurs in a COX-1-dependent manner [106]. Lipid profiling of the synovial fluid of RA patients demonstrated significant amounts of platelet-related mediators, showing disproportion favouring pro-inflammatory lipids, such as LTB4 isomers [107]. In a mouse, model of RA resolution of inflammation is disrupted by inhibition of COX-2, but can be restored by lipoxins [108]. PMP in the synovial fluid of RA patients are highly heterogeneous in size. Larger microparticles were found to contain immune complexes (IC), which, moreover, responded to majority of the IC detected [109]. Immunoglobulins and complement are associated with majority of PMP in RA synovial fluid.
PMP express platelet-derived antigens and associate with autoantigens from other sources that are present in plasma [53]. Platelet-derived antigens include intracellular proteins, such as vimentin. Vimentin externalisation occurs during platelet activation. PMP surface may be a site of further post-transcriptional autoantigen modifications, for example, citrullinisation [110]. This results in the generation of neoepitopes, recognized by autoantibodies characteristic for RA [111]. Complement proteins can bind to PMP surface. Highly bound $\mathrm{C} 1 \mathrm{q}, \mathrm{C} 3$, and $\mathrm{C} 4$ complement components are characteristic for PMP in the synovial fluid of RA patients. These immune complexes were showed to strongly activate neutrophils. Self-sustaining activation of platelets and neutrophils at the site of synovial bleeding may synergize in the formation of citrullinated fibrinogen and vimentin neoepitopes [110]. Proteins of platelet origin are being transformed by peptidylarginine deiminase 4 (PAD4): a neutrophil-derived enzyme [112]. Upheld activation of platelets and neutrophils results in NETosis which, in turn, strongly activates FLS. FLS are capable of internalising NETs. It induces antigen-presenting cell properties in FLS, which can now present platelet-derived, post-transcriptionally modified autoantigens. The process supports autoimmunity $[20,113]$.

Finally, platelets contribute to RA synovitis by maintaining persistent permeability of synovial microvasculature. They activate endothelial cells what results in the expression of surface adhesion molecules and enables cell migration [62]. Platelets release serotonin in the spots of vascular damage which cause formation of endothelial gaps with submicron dimension. It favours synovial infiltration by inflammatory cells [114, Fig. 2].

Systemic Sclerosis $(\mathrm{SSc})$ is a heterogenous and complex autoimmune disorder with three main components: production of autoantibodies and cell-mediated autoimmunity, vascular damage leading to fibroproliferative vasculopathy and fibroblast dysfunction consisting of excessive accumulation of collagen in organs [115].

Patients suffering from SSc have increased blood levels of platelet activation markers and higher platelet aggregation ratio in comparison with healthy subjects [116-119]. The suggested reason was endothelial dysfunction, considered the primary event in SSc. Subsets of enlarged von Willebrand multimers were found in their plasma, revealing another cause of chronic activation [120]. Platelets become hypersensitive to activating factors such as serotonin, adrenalin, ADP, and collagen. In fact, characteristic overexpression of the non-integrin receptor for collagen I was found in SSc patient platelets. There is growing evidence for existence of a network between platelets and autoreactive $\mathrm{T}$ lymphocytes specific against collagen I. Autoreactive $\mathrm{T}$ cells produce IFN $\gamma$ and IL-1, which stimulate megakaryocyte expression of PI3K and Akt. This results in overexpression of these signatures of activation on platelets, enhanced 


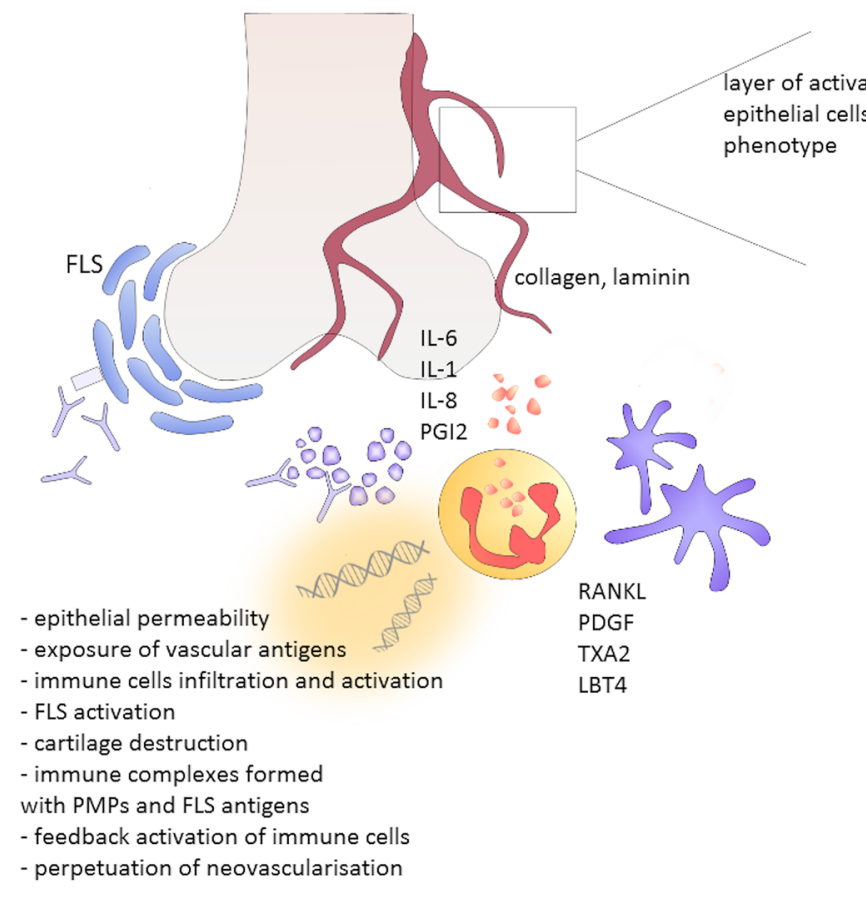

Within the joint

Fig. 2 Platelet role in the pathogenesis of rheumatoid arthritis

response to collagen I, and platelet aggregation. Exposure to collagen I increases with the disease progression, depicted by gradual fibrosis [120].

5-HT signalling seems to be of particular importance in the activation of platelets in SSc. Concomitant excessive levels of 5-HT in circulation and defective platelet content were found. The presence of a polymorphism in the gene for the serotonin $2 \mathrm{~A}$ receptor, resulting in weaker platelet activation and aggregation, was associated with reduced susceptibility to SSc and alleviation of the course of the disease [121].

Activated platelets release stored granule contents, and the releasates contribute to imbalance between vasodilators and vasoconstrictors and enhance fibrosis [122]. The mechanisms are well described for lysophospholipids, 5-HT, PDGF, TGF $\beta$, and other growth factors. VEGF stimulates angiogenesis, PDGF activates smooth muscle cells and connective tissue fibroblasts proliferation, and TGF $\beta$ may increase collagen and matrix components synthesis. The angiogenesis-promoting factors, however, seem to be inhibited by anti-angiogenic mediators such as PF4, which together with pro-inflammatory and pro-fibrotic agents, contribute to the progression of microvascular damage, defective vascular repair, consequent hypoxia, and fibrosis in patients with SSc [123]. Platelet-derived HMGB1 serum level is higher in SSc patients and associated with microvascular damage [49]. CXCL4, a potent anti-angiogenic chemokine secreted by platelets and dendritic cells, was recognized as parameter predicting disease progression and organ complications [124].

Persistent platelet activation implicates deregulation of platelet-neutrophil interactions [112]. Cell aggregates produce pro-inflammatory lipids, and neutrophils release matrix-degradation enzymes and superoxide radicals. These humoral and cellular components alter the process of reperfusion what results in self-sustaining vasculitis, vascular remodelling, and inflammation [56].

Systemic lupus Erythematosus (SLE) In SLE, chronic, systemic inflammation is associated with the formation of autoantibodies and immune complexes, and their subsequent deposition is tissues and eventual organ damage [125]. B cells become hyperactive as a result of escalated stimulation from autoantigens exposed on the surface of apoptotic cells, enhanced by $\mathrm{T}$ lymphocytes and other immune cells.

SLE has many haematological manifestations, including thrombocytopenia. Low platelet count is more frequent in SLE patients than increased platelet number [126]. It has been associated with other severe symptoms such as kidney injury, haemolytic anaemia, neuropsychiatric manifestations, and a worse course of the disease [91]. At the same time, the following evident markers of platelet activation are increased in the blood of SLE patients: thromboxane, P-selectin, PMP, and platelet-leukocyte aggregates. Circulating immune complexes, high-affinity antibodies against nuclear constituents, 
the hallmark of SLE, can activate platelets via the FcyRIIA receptor [87].

Activated platelets contribute to the maturation of dendritic cells (DC) [127]; these are crucial in the pathogenesis of SLE, as their interactions with B-and T cells lead to the production of autoantibodies, including those against nuclear antigens (ANA) and DNA (anti-ds-DNA). PMP-associated CD154 can cause DC activation and soluble CD154 levels were found to be increased in SLE patients and to correlate with disease activity measured by SLE Disease Activity Index. Level of CD154 correlates positively with the presence of anti-phospholipid antibodies in SLE patients [128]. Platelet association with DC promotes the secretion of type I IFN(IFN) [129], which is another important constituent of SLE pathogenesis [130]. In addition, platelets from SLE patients were found to over-express IFN-regulated genes, resulting in up-regulated numbers of the proteins PRKRA, IFITM1, and CD69 leading to increased activation of platelets from SLE patients associated with the type I IFN response [130].

Moreover, platelets themselves and PMP are a source of autoantigens involved in the formation of immune complexes [53]. Platelet autoantibodies were found in SLE patients [131]. The majority of circulating immune complexes formed with microparticles are of platelet origin. PMP may deliver ANA and anti-ds-DNA antibodies, both of which are potent pro-inflammatory agents. Circulating PMP in SLE patients carry increased loads of $\operatorname{IgG}, \operatorname{IgM}$, and C1q [132]. IgG PMP are associated with autoantibodies and complement activation, their level correlated with anti-DNA antibodies titres. The platelet surface may also be the site of complement activation and deposition. It has been described as a target for circulating anti-phospholipid antibodies (aPL), with the major antigen recognized by aPL being $\beta 2$ glycoprotein 1, a member of the complement control protein superfamily [87]. The interaction can occur by mechanisms other than direct recognition of platelet antigens, such as by crosslinking of the apolipoprotein ER2' receptor, and with the involvement of the FcyRIIA receptor. The complement $\mathrm{Cd} 4$ protein specifically accumulates on the platelet surface in SLE patients, correlates with disease activity, and is associated with the presence of anti-phospholipids [20].

A large number of SLE autoantigens is exposed in close proximity to the oxidant-generating site, and this is another way in which platelets may promote autoantigen formation [133]. More frequently, deregulated interactions between platelets and neutrophils occur in SLE [112]: PMP-IC elicit leukotriene production and NET generation by neutrophils $[60,127]$. Nuclear autoantigens, including ds-DNA, histones, ANA, and neutrophil cytoplasmic antigens all serve as major component of NETs [131]. NET degradation is impaired in SLE, and patients with defective NET degradation have significantly higher titres of anti-NET and
anti-ds-DNA autoantibodies, as well as a higher frequency of developing lupus nephritis. Deregulated platelet-neutrophil interactions result in the creation of a self-sustaining cycle of oxidant generation and necrotic cell formation that stimulates the autoimmune response.

SLE patients have an increased risk of developing cardiovascular disease, stroke, and venous thrombosis, which cannot be explained by classic cardiac risk factors [134]. Platelet activation seems to be a potential link between atherosclerotic lesions and systemic inflammation [20], and many patients have been diagnosed with comorbidity of SLE and APS [8].

Anti-phospholipid Syndrome (APS) is a systemic autoimmune disorder directly associated with thrombotic and cardiovascular risk [135]. In addition, anti-phospholipid antibodies are present in around $40 \%$ of SLE patients [87], around $20 \%$ of RA patients and around $10 \%$ of SSc patients [136].

Anti-phospholipid antibodies (APLs), particularly lupus anticoagulant, anticardiolipin antibodies (aCL), and anti$\beta(2)$-glycoprotein I (anti- $\beta 2$ GPI), are a family of antibodies against phospholipids that can exert pathogenic effects. These antibodies may interfere with the membrane phospholipids of endothelial cells and platelets, or with the bioactive phospholipids of signalling cascades, including the coagulation cascade [137]. Circulating anti-phospholipid antibodies with anti- $\beta 2$ GPI activity recognize endothelial cells, which synthesize TF4 and express adhesion molecules such as ICAM1 and E-selectin upon recognition. This synthesis results in platelet activation and increased TXA2 production. High levels of TF4 and TXA2 mediate the procoagulant state: a known risk factor of thrombosis.

Thrombocytopenia is commonly observed among APS patients, and the most common determinant autoantigen described is platelet $\beta 2$-glycoprotein I ( $\beta 2$-GPI). $\beta 2$-GPI is an apolipoprotein which plays a complex role in blood coagulation. Its active form exposes an epitope recognized by specific IgG autoantibodies. Binding the autoantibodies to $\beta 2$-GPI results in the formation of a macromolecular complex, PF4- $\beta 2-G P I-a n t i-\beta 2-G P I$, that contributes significantly to platelet activation [63]. Platelets may thus be perceived as the primary target of anti-phospholipid antibodies [138], although aCL antibodies can only bind to platelet plasma membrane phospholipids after activation, as the major binding targets are the anionic phospholipids of the inner layer of the membrane. Enhanced platelet activation sustained over time is related to vascular dysfunction and progressive damage, thrombotic events, and complement activation [139]. Immune complexes containing $\mathrm{C} 4 \mathrm{~d}$ and $\mathrm{C} 3 \mathrm{~b}$ complement proteins have been found to be deposited in the placentas of APS patients [87]. Activated platelets produce thrombopoietin and contribute to increased platelet turnover, which represents a positive regulatory loop. Despite the augmented 
production and accelerated maturation of platelets, up to $50 \%$ of APS patients develop thrombocytopenia, usually explained as a result of excessive platelet destruction [138].

PMP are significantly increased in APS patients, especially in those with APS secondary to SLE or patients with a history of thrombotic complications [63]. A study of APS thrombus composition revealed a great number of PMP. A higher level of platelet-derived bioactive releasates was also found in APS patients, with most being CXCL4 (PF4) [128]. In APS patients, $\mathrm{PF} 4$ interacts with the anti- $\beta 2$-GPI- $\beta 2$-GPI macromolecule and further enhances platelet activation. The levels of platelet-leukocyte aggregates are significantly higher in APS patients compared to a healthy population [63].

\section{Evaluation of platelet activity in clinical practice}

The platelet indices such as a mean platelet volume (MPV) and platelet distribution width (PDW) are currently under investigation as possible new indicators of platelet activation. Since they are routinely evaluated as a part of a complete blood count test, they could become a cheap and highly accessible measurement of platelet parameters. The hypothesis is based on the fact that upon activation platelets increase volume and form pseudopodia. Several research teams have attempted to correlate MPV with the RA, SSc, and SLE disease severity and cardiovascular risk; however, they have reported contradictory results [63, 90, 92, 128, 140-142]. In SLE, smaller platelet size was proved to correlate with greater platelet activation, PMP formation, the presence of aCL antibodies, and secondary APS [143]. Changes to MPV have also been investigated in response to the RA treatment with anti-TNF $\alpha$ agent. A recent study showed that platelet count decreased and MPV increased at the end of the treatment period [144]. These discrepancies may be due to a magnitude of variables influencing MPV with age and sex being just the tip of the iceberg. There is an inverse correlation between platelet count and MPV and there are large interindividual differences between both the indices. MPV is also a parameter prone to change upon pre-analytical variabilities [145]. Due to MPV variability, one research team has identified PDW as a more specific marker of platelet activation of coagulation [146]. Even then, there are significant differences in measuring MPV and PDW among blood counters [147]. It remains controversial whether platelet indices correlate with the optical aggregometry results [148].

Another challenge in the interpretation of platelet indices in the systemic $\mathrm{AD}$ is the vast prevalence of atherothrombosis among patients. MPV is a well-established predictor of cardiovascular risk [149]. Increased MPV was associated with an acute myocardial infarction, ischemic stroke, and atrial fibrillation [150]. High MPV predicts a poor outcome of these events [151]. As rheumatic disorders are known to increase the risk of atherosclerosis and its complications, it cannot be excluded that increased MPV in AD reflects the existing subclinical atherosclerosis. Therefore, altered MPV value in AD patients could be an expression of an overlapping cardiovascular disease. At the same time, both systemic $\mathrm{AD}$ and chronic inflammatory diseases (including cardiovascular disease) are characterized by a high level of IL6. IL6 may stimulate the bone marrow to an increased release of younger, bigger platelets [152].

Future studies could investigate these issues further by designing research protocols including several different methods of platelet reactivity assessment. This includes well documented methods such as light transmission aggregometry, flow cytometry, and quantification of platelet-derived soluble proteins in blood plasma.

\section{Conclusions}

Platelets recently became an intriguing topic of research on mechanisms of autoimmunity. Growing evidence on platelet role in autoimmune disorders is being delivered by independent research teams.

There is no doubt that platelets are a source of autoantigens. Their prolonged activation may lead to the recognition of surface molecules by autoantibodies, or to their enzymatic transformation and the formation of neoepitopes. In autoimmune-mediated inflammation, platelets act as a component of the positive feedback loop response by secreting and synthesising vast amounts of bioactive compounds. They contribute to pathological hallmarks of autoimmune inflammation such as: extensive complement activation, circulation of immune complexes, impaired phagocytosis of apoptotic cells, and NETs. Platelets promote T helper leukocyte maturation towards type 1 and type 17, associated with autoimmunity. Costimulation signal delivered by platelets enable maturation of antibodies affinity. The enzymes and growth factors delivered by platelets facilitate tissue degeneration and neovasculogenesis. Mechanisms and pathways described for platelets in the context of AD overlap with those characteristic of thrombosis and atherosclerosis, which explains the increased cardiovascular risk of AD patients [5, 8, 88, 153].

However, platelets also play an opposite role. They are indispensable in the production of pro-resolution and antiinflammatory lipid mediators, which trigger adaptive immunity, promoting a shift in balance between types of Th lymphocytes and dendritic cells. These compounds enhance the clearing of apoptotic cells and immune complexes-potential autoantigens. Platelet-rich plasma (PRP) infusions are widely applied in treating joint trauma, as platelet-derived growth factors have a positive influence on chondrocytes $[154,155]$. A recent study proposes an immunological 
mechanism of resolving antigen-induced arthritis and implementation of PRP infusions in rheumatology. In a porcine model of RA, PRP was found to alleviate disease symptoms [156]. Platelets can internalize larger IgG-coated particles in a process similar in some respects to phagocytosis in leukocytes, thus supporting the clearance of immune complexes. Finally, platelet binding to Th lymphocytes reduce their ability to produce cytokines typical for autoimmunity-related subtypes.

The evidence for platelet involvement in the patomechanisms of autoimmune disorders suggests that platelets play either a pro- or anti-inflammatory role depending on the inflammation-initiating stimuli $[28,157,158]$. The main limitation of the most of the available studies is that they only present a selected phase of platelet activity. Furthermore, they often use a single marker to assess it. It would be important for the future research to present platelet activity as a dynamic, variable process. A further investigation of the platelet traditional indices (like MPV and PDW) and the other markers (soluble platelet-derived protein assays, flow cytometry, PMP, and optical aggregometry) could provide an attractive tool for clinicians. It would be worth to investigate the influence of the available anti-rheumatic medication on platelet function. Other examples of the potential areas for further research include, for instance, the role of platelet-derived miRNA in AD or PMP as carriers of bioactive molecules. The authors hope that the exploration of the role of platelets as a potential therapeutic target and a possible ally in the treatment of autoimmune disorders will continue.

Author contributions ZMŁ was responsible for writing the article and designing artwork. MM was responsible for literature research and critical revision of the article. JSM was responsible for article concept and design and approved the final version to be submitted for publication.

Funding Not applicable.

\section{Compliance with ethical standards}

Conflict of interest Zuzanna Małgorzata Łukasik declares that she has no conflict of interest. Marcin Makowski declares that he has no conflict of interest. Joanna Samanta Makowska declares that she has no conflict of interest.

Human and animal rights statement This article does not contain any studies with human participants performed by any of the authors.

Open Access This article is distributed under the terms of the Creative Commons Attribution 4.0 International License (http://creativeco mmons.org/licenses/by/4.0/), which permits unrestricted use, distribution, and reproduction in any medium, provided you give appropriate credit to the original author(s) and the source, provide a link to the Creative Commons license, and indicate if changes were made.

\section{References}

1. de Gaetano G (2001) Historical overview of the role of platelets in hemostasis and thrombosis. Haematologica 86:349-356

2. Patel SR, Hartwig JH, Italiano JE (2005) The biogenesis of platelets from megakaryocyte proplatelets. Journal of Clinical Investigation 115:3348-3354. https://doi.org/10.1172/JCI26891

3. Machlus KR, Thon JN, Italiano JE (2014) Interpreting the developmental dance of the megakaryocyte: a review of the cellular and molecular processes mediating platelet formation. Br J Haematol 165(2):227-236. https://doi.org/10.1111/bjh.12758

4. Garraud O, Cognasse F (2015) Are platelets cells? And if yes, are they immune cells? Front Immunol 6:70. https://doi.org/10.3389/ fimmu.2015.00070

5. Amaya-Amaya J, Montoya-Sánchez L, Rojas-Villarraga A (2014) Cardiovascular involvement in autoimmune diseases. Biomed Res Int 2014:367359. https://doi.org/10.1155/2014/367359

6. Golebiewska EM, Poole AW (2015) Platelet secretion: from haemostasis to wound healing and beyond. Blood Rev 29:153-162. https://doi.org/10.1016/j.blre.2014.10.003

7. Vieira-de-Abreu A, Campbell RA, Weyrich AS, Zimmerman GA (2012) Platelets: versatile effector cells in hemostasis, inflammation, and the immune continuum. Semin Immunopathol 34:5-30. https://doi.org/10.1007/s00281-011-0286-4

8. Cunningham M, Marks N, Barnado A, Wirth JR, Gilkeson G, Markiewicz M (2014) Are microparticles the missing link between thrombosis and autoimmune diseases? Involvement in selected rheumatologic diseases. Semin Thromb Hemost 40:675681. https://doi.org/10.1055/s-0034-1387924

9. Barry OP, Pratico D, Lawson JA, FitzGerald GA (1997) Transcellular activation of platelets and endothelial cells by bioactive lipids in platelet microparticles. J Clin Invest 99:2118-2127. https://doi.org/10.1172/JCI119385

10. Stokes KY, Granger DN (2012) Platelets: a critical link between inflammation and microvascular dysfunction. J Physiol 590:1023-1034. https://doi.org/10.1113/jphysiol.2011.225417

11. Herter JM, Rossaint J, Zarbock A (2014) Platelets in inflammation and immunity. J Thromb Haemost 12:1764-1775. https:// doi.org/10.1111/jth. 12730

12. Lam FW, Vijayan KV, Rumbaut RE (2015) Platelets and their interactions with other immune cells. Compr Physiol 5:12651280. https://doi.org/10.1002/cphy.c140074

13. Ghoshal K, Bhattacharyya M (2014) Overview of platelet physiology: its hemostatic and nonhemostatic role in disease pathogenesis. Sci World J 2014:7818-7857. https://doi. org/10.1155/2014/781857

14. Garraud O, Cognasse F (2010) Platelet Toll-like receptor expression: the link between "danger" ligands and inflammation. Inflamm Allergy Drug Targets 9:322-333. https://doi. org/10.2174/187152810793937991

15. Li C, Li J, Li Y, Lang S, Yougbare I, Zhu G et al. (2012) Crosstalk between platelets and the immune system: old systems with new discoveries. Adv Hematol 2012:384685. https://doi. org/10.1155/2012/384685

16. Solpov A, Shenkman B, Vitkovsky Y, Brill G, Koltakov A, Farzam N et al (2006) Platelets enhance CD4+ lymphocyte adhesion to extracellular matrix under flow conditions: role of platelet aggregation, integrins, and non-integrin receptors. Thromb Haemost 95:815-821

17. Arman M, Krauel K (2015) Human platelet IgG Fc receptor Fc $\gamma$ RIIA in immunity and thrombosis. J Thromb Haemost 13:893-908. https://doi.org/10.1111/jth.12905

18. Cognasse F, Nguyen KA, Damien P, McNicol A, Pozzetto B, Hamzeh-Cognasse $\mathrm{H}$ et al (2015) The inflammatory role of 
platelets via their TLRs and Siglec receptors. Front Immunol 6:83. https://doi.org/10.3389/fimmu.2015.00083

19. Bennett JS, Berger BW, Billings PC (2009) The structure and function of platelet integrins. J Thromb Haemost 7:200-205. https://doi.org/10.1111/j.1538-7836.2009.03378.x

20. Peerschke EI, Yin W, Ghebrehiwet B (2010) Complement activation on platelets: implications for vascular inflammation and thrombosis. Mol Immunol 47:2170-2175. https://doi. org/10.1016/j.molimm.2010.05.009

21. Nurden AT (2011) Platelets, inflammation and tissue regeneration. Thromb Haemost 105:13-33. https://doi.org/10.1160/ THS10-11-0720

22. Morrell CN, Aggrey AA, Chapman LM, Modjeski KL (2014) Emerging roles for platelets as immune and inflammatory cells. Blood 123:2759-2767. https://doi.org/10.1182/blood-2013-11462432

23. Rendu F, Brohard-Bohn B (2001) The platelet release reaction: granules' constituents, secretion and functions. Platelets 12:261273. https://doi.org/10.1080/09537100120068170

24. Coppinger JA, Maguire PB (2007) Insights into the platelet releasate. Curr Pharm Des 13:2640-2646. https://doi. org/10.2174/138161207781662885

25. Blair P, Flaumenhaft R (2009) Platelet alpha-granules: basic biology and clinical correlates. Blood Rev 23:177-189. https://doi. org/10.1016/j.blre.2009.04.001

26. Stocker TJ, Ishikawa-Ankerhold H, Massberg S, Schulz C (2017) Small but mighty: platelets as central effectors of host defense. Thromb Haemost 117:651-661. https://doi.org/10.1160/ TH16-12-0921

27. Joshi S, Whiteheart SW (2017) The nuts and bolts of the platelet release reaction. Platelets 28:129-137. https://doi. org/10.1080/09537104.2016.1240768

28. Manne BK, Xiang SC, Rondina MT (2017) Platelet secretion in inflammatory and infectious diseases. Platelets 28:155-164. https ://doi.org/10.1080/09537104.2016.1240766

29. Mancuso ME, Santagostino E (2017) Platelets: much more than bricks in a breached wall. Br J Haematol 178:209-219. https:// doi.org/10.1111/bjh.14653

30. Coppinger JA, Cagney G, Toomey S, Kislinger T, Belton O, McRedmond JP et al (2004) Characterization of the proteins released from activated platelets leads to localization of novel platelet proteins in human atherosclerotic lesions. Blood 103:2096-2104. https://doi.org/10.1182/blood-2003-08-2804

31. Gresele P, Kleiman NS, Lopez JA, Page CP (2017) Platelets in thrombotic and non-thrombotic disorders. Pathophysiology, pharmacology and therapeutics: an update. Springer International Publishing, New York

32. Elzey BD, Sprague DL, Ratliff TL (2005) The emerging role of platelets in adaptive immunity. Cell Immunol 238:1-9. https:// doi.org/10.1016/j.cellimm.2005.12.005

33. Jin R, Yu S, Song Z, Zhu X, Wang C, Yan J et al (2013) Soluble CD40 ligand stimulates CD40-dependent activation of the $\beta 2$

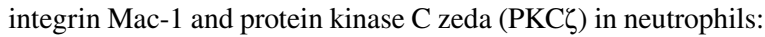
implications for neutrophil-platelet interactions and neutrophil oxidative burst. PLoS One 8(6):e64631. https://doi.org/10.1371/ journal.pone. 0064631

34. Sprague DL, Elzey BD, Crist SA, Waldschmidt TJ, Jensen RJ, Ratliff TL (2008) Platelet-mediated modulation of adaptive immunity: unique delivery of CD154 signal by platelet-derived membrane vesicles. Blood 111(6):5028-5036. https://doi. org/10.1182/blood-2007-06-097410

35. Inwald DP, McDowall A, Peters MJ, Callard RE, Klein NJ (2003) CD40 is constitutively expressed on platelets and provides a novel mechanism for platelet activation. Circ Res 92:1041-1048. https://doi.org/10.1161/01.RES.0000070111.98158.6C
36. Emadi S, Mirshahi M, Elalamy I, Nicolas C, Vargaftig BB, Hatmi M (1998) Cellular source of human platelet secretory phospholipase A2. Br J Haematol 100:365-373

37. Denis MM, Tolley ND, Bunting M, Schwertz H, Jiang H, Lindemann $S$ et al (2005) Escaping the nuclear confines: signaldependent pre-mRNA splicing in anucleate platelets. Cell 122:379-391. https://doi.org/10.1016/j.cell.2005.06.015

38. Dinarello CA (2011) Interleukin-1 in the pathogenesis and treatment of inflammatory diseases. Blood 117:3720-3732. https:// doi.org/10.1182/blood-2010-07-273417

39. Lindemann S, Tolley ND, Dixon DA, McIntyre TM, Prescott SM, Zimmerman GA et al (2001) Activated platelets mediate inflammatory signaling by regulated interleukin 1 beta synthesis. J Cell Biol 154:485-490. https://doi.org/10.1083/jcb.200105058

40. Beaulieu LM, Freedman JE (2009) NFkappaB regulation of platelet function: no nucleus, no genes, no problem? J Thromb Haemost 7:1329-1332. https://doi.org/10.111 1/j.1538-7836.2009.03505.x

41. Plé H, Landry P, Benham A, Coarfa C, Gunaratne PH, Provost $P$ (2012) The repertoire and features of human platelet microRNAs. PLoS One 7(12):e50746. https://doi.org/10.1371/journ al.pone. 0050746

42. Ceribelli A, Yao B, Dominguez-Gutierrez PR, Nahid MA, Satoh M, Chan EK (2011) MicroRNAs in systemic rheumatic diseases. Arthritis Res Ther 13:229. https://doi.org/10.1186/ ar3377

43. Norling LV, Dalli J (2013) Microparticles are novel effectors of immunity. Curr Opin Pharmacol 13:570-575. https://doi. org/10.1016/j.coph.2013.05.008

44. Italiano JE, Mairuhu AT, Flaumenhaft R (2010) Clinical relevance of microparticles from platelets and megakaryocytes. Curr Opin Hematol 17:578-584. https://doi.org/10.1097/MOH.0b013 e32833e77ee

45. Garcia BA, Smalley DM, Cho H, Shabanowitz J, Ley K, Hunt DF (2005) The platelet microparticle proteome. J Proteome Res 4:1516-1521. https://doi.org/10.1021/pr0500760

46. Melki I, Tessandier N, Zufferey A, Boilard E (2017) Platelet microvesicles in health and disease. Platelets 28:214-221. https ://doi.org/10.1080/09537104.2016.1265924

47. Mause SF, von Hundelshausen P, Zernecke A, Koenen RR, Weber C (2005) Platelet microparticles: a transcellular delivery system for RANTES promoting monocyte recruitment on endothelium. Arterioscler Thromb Vasc Biol 25:1512-1518. https://doi.org/10.1161/01.ATV.0000170133.43608.37

48. Diehl P, Fricke A, Sander L, Stamm J, Bassler N, Htun N et al (2012) Microparticles: major transport vehicles for distinct microRNAs in circulation. Cardiovasc Res 93:633-644. https:// doi.org/10.1093/cvr/cvs007

49. Maugeri N, Franchini S, Campana L, Baldini M, Ramirez GA, Sabbadini MG et al (2012) Circulating platelets as a source of the damage-associated molecular pattern HMGB1 in patients with systemic sclerosis. Autoimmunity 45:584-587. https://doi. org/10.3109/08916934.2012.719946

50. Reich N, Beyer C, Gelse K, Akhmetshina A, Dees C, Zwerina J et al (2011) Microparticles stimulate angiogenesis by inducing ELR(+) CXC-chemokines in synovial fibroblasts. J Cell Mol Med 15:756-762. https://doi.org/10.1111/j.1582-4934.2010.01051.x

51. Berckmans RJ, Nieuwland R, Böing AN, Romijn FP, Hack CE, Sturk A (2001) Cell-derived microparticles circulate in healthy humans and support low grade thrombin generation. Thromb Haemost 85:639-646

52. Biró E, Nieuwland R, Tak PP, Pronk LM, Schaap MC, Sturk A et al (2007) Activated complement components and complement activator molecules on the surface of cell-derived microparticles in patients with rheumatoid arthritis and healthy 
individuals. Ann Rheum Dis 66:1085-1092. https://doi. org/10.1136/ard.2006.061309

53. Cloutier N, Tan S, Boudreau LH, Cramb C, Subbaiah R, Lahey L et al (2013) The exposure of autoantigens by microparticles underlies the formation of potent inflammatory components: the microparticle-associated immune complexes. EMBO Mol Med 5:235-249. https://doi.org/10.1002/emmm.201201846

54. Passacquale G, Vamadevan P, Pereira L, Hamid C, Corrigall V, Ferro A (2011) Monocyte-platelet interaction induces a proinflammatory phenotype in circulating monocytes. PLoS One 6(10):e25595. https://doi.org/10.1371/journal.pone.0025595

55. Barnard MR, Linden MD, Frelinger AL, Li Y, Fox ML, Furman MI et al (2005) Effects of platelet binding on whole blood flow cytometry assays of monocyte and neutrophil procoagulant activity. J Thromb Haemost 3:2563-2570. https://doi.org/10.11 11/j.1538-7836.2005.01603.x

56. Kim SJ, Jenne CN (2016) Role of platelets in neutrophil extracellular trap (NET) production and tissue injury. Semin Immunol 28:546-554. https://doi.org/10.1016/j.smim.2016.10.013

57. Pfeiler S, Stark K, Massberg S, Engelmann B (2017) Propagation of thrombosis by neutrophils and extracellular nucleosome networks. Haematologica 102:206-213. https://doi.org/10.3324/ haematol.2016.142471

58. Sangaletti S, Tripodo C, Chiodoni C, Guarnotta C, Cappetti B, Casalini P et al (2012) Neutrophil extracellular traps mediate transfer of cytoplasmic neutrophil antigens to myeloid dendritic cells toward ANCA induction and associated autoimmunity. Blood 120:3007-3018. https://doi.org/10.1182/blood-2012-03416156

59. Zarbock A, Polanowska-Grabowska RK, Ley K (2007) Plateletneutrophil-interactions: linking hemostasis and inflammation. Blood Rev 21:99-111. https://doi.org/10.1016/j.blre.2006.06.001

60. Maugeri N, Campana L, Gavina M, Covino C, De Metrio M, Panciroli C et al (2014) Activated platelets present high mobility group box 1 to neutrophils, inducing autophagy and promoting the extrusion of neutrophil extracellular traps. J Thromb Haemost 12:2074-2088. https://doi.org/10.1111/jth.12710

61. Serhan CN, Sheppard KA (1990) Lipoxin formation during human neutrophil-platelet interactions. Evidence for the transformation of leukotriene A4 by platelet 12-lipoxygenase in vitro. J Clin Invest 85:772-780. https://doi.org/10.1172/JCI114503

62. Gros A, Ollivier V, Ho-Tin-Noé B (2014) Platelets in inflammation: regulation of leukocyte activities and vascular repair. Front Immunol 5:678. https://doi.org/10.3389/fimmu.2014.00678

63. Joseph JE, Harrison P, Mackie IJ, Isenberg DA, Machin SJ (2001) Increased circulating platelet-leucocyte complexes and platelet activation in patients with antiphospholipid syndrome, systemic lupus erythematosus and rheumatoid arthritis. $\mathrm{Br} \mathrm{J}$ Haematol 115:451-459. https://doi.org/10.1046/j.1365-2141.2001.03101 . $\mathrm{X}$

64. Li N, Ji Q, Hjemdahl P (2006) Platelet-lymphocyte conjugation differs between lymphocyte subpopulations. J Thromb Haemost 4:874-881. https://doi.org/10.1111/j.1538-7836.2006.01817.x

65. Zamora C, Cantó E, Nieto JC, Ortiz MA, Diaz-Torné C, DiazLopez C et al (2013) Functional consequences of platelet binding to T lymphocytes in inflammation. J Leukoc Biol 94:521-529. https://doi.org/10.1189/jlb.0213074

66. Gerdes N, Zhu L, Ersoy M, Hermansson A, Hjemdahl P, Hu H et al (2011) Platelets regulate $\mathrm{CD}^{+}{ }^{+} \mathrm{T}$-cell differentiation via multiple chemokines in humans. Thromb Haemost 106:353-362. https://doi.org/10.1160/TH11-01-0020

67. Zhu L, Huang Z, Stålesen R, Hansson GK, Li N (2014) Platelets provoke distinct dynamics of immune responses by differentially regulating CD4+ T-cell proliferation. J Thromb Haemost 12:1156-1165. https://doi.org/10.1111/jth.12612
68. Marder W, Khalatbari S, Myles JD, Hench R, Yalavarthi S, Lustig $S$ et al (2011) Interleukin 17 as a novel predictor of vascular function in rheumatoid arthritis. Ann Rheum Dis 70:1550-1555. https://doi.org/10.1136/ard.2010.148031

69. Dinkla S, van Cranenbroek B, van der Heijden WA, He X, Wallbrecher R, Dumitriu IE et al (2016) Platelet microparticles inhibit IL-17 production by regulatory $\mathrm{T}$ cells through $\mathrm{P}$-selectin. Blood 127:1976-1986. https://doi.org/10.1182/blood-2015-04-640300

70. Cognasse F, Hamzeh-Cognasse H, Lafarge S, Chavarin P, Cogné M, Richard Y et al (2007) Human platelets can activate peripheral blood B cells and increase production of immunoglobulins. Exp Hematol 35:1376-1387. https://doi.org/10.1016/j.exphe m.2007.05.021

71. Chapman LM, Aggrey AA, Field DJ, Srivastava K, Ture S, Yui $\mathrm{K}$ et al (2012) Platelets present antigen in the context of MHC class I. J Immunol 189:916-923. https://doi.org/10.4049/jimmu nol.1200580

72. Capra V, Rovati GE, Mangano P, Buccellati C, Murphy RC, Sala A (2015) Transcellular biosynthesis of eicosanoid lipid mediators. Biochim Biophys Acta 1851:377-382. https://doi. org/10.1016/j.bbalip.2014.09.002

73. Folco G, Murphy RC (2006) Eicosanoid transcellular biosynthesis: from cell-cell interactions to in vivo tissue responses. Pharmacol Rev 58:375-388. https://doi.org/10.1124/pr.58.3.8

74. Li Z, Delaney MK, O'Brien KA, Du X (2010) Signaling during platelet adhesion and activation. Arterioscler Thromb Vasc Biol 30:2341-2349. https://doi.org/10.1161/ATVBAHA.110.207522

75. Marcus AJ, Broekman MJ, Safier LB, Ullman HL, Islam N, Sherhan CN et al (1982) Formation of leukotrienes and other hydroxy acids during platelet-neutrophil interactions in vitro. Biochem Biophys Res Commun 109:130-137

76. Aldrovandi M, Hinz C, Lauder SN, Podmore H, Hornshaw M, Slatter DA et al (2017) DioxolaneA3-phosphatidylethanolamines are generated by human platelets and stimulate neutrophil integrin expression. Redox Biol 11:663-672. https://doi.org/10.1016/j. redox.2017.01.001

77. Serhan CN, Chiang N, Van Dyke TE (2008) Resolving inflammation: dual anti-inflammatory and pro-resolution lipid mediators. Nat Rev Immunol 8:349-361. https://doi.org/10.1038/nri2294

78. Fierro IM, Serhan CN (2001) Mechanisms in anti-inflammation and resolution: the role of lipoxins and aspirin-triggered lipoxins. Braz J Med Biol Res 34:555-566. https://doi.org/10.1590/S0100 -879X2001000500002

79. Fredman G, Van Dyke TE, Serhan CN (2010) Resolvin E1 regulates adenosine diphosphate activation of human platelets. Arterioscler Thromb Vasc Biol 30:2005-2013. https://doi.org/10.1161/ ATVBAHA.110.209908

80. Abdulnour RE, Dalli J, Colby JK, Krishnamoorthy N, Timmons JY, Tan SH et al (2014) Maresin 1 biosynthesis during plateletneutrophil interactions is organ-protective. Proc Natl Acad Sci U S A 111:16526-16531. https://doi.org/10.1073/pnas.1407123111

81. Lannan KL, Spinelli SL, Blumberg N, Phipps RP (2017) Maresin 1 induces a novel pro-resolving phenotype in human platelets. $\mathrm{J}$ Thromb Haemost 15:802-813. https://doi.org/10.1111/jth.13620

82. Hong S, Lu Y, Tian H, Alapure BV, Wang Q, Bunnell BA et al (2014) Maresin-like lipid mediators are produced by leukocytes and platelets and rescue reparative function of diabetesimpaired macrophages. Chem Biol 21:1318-1329. https://doi. org/10.1016/j.chembiol.2014.06.010

83. Choy E, Ganeshalingam K, Semb AG, Szekanecz Z, Nurmohamed M (2014) Cardiovascular risk in rheumatoid arthritis: recent advances in the understanding of the pivotal role of inflammation, risk predictors and the impact of treatment. Rheumatology 53:2143-2154. https://doi.org/10.1093/rheumatology/ keu224 
84. Agca R, Heslinga SC, Rollefstad S, Heslinga M, McInnes IB, Peters MJ et al (2017) EULAR recommendations for cardiovascular disease risk management in patients with rheumatoid arthritis and other forms of inflammatory joint disorders: 2015/2016 update. Ann Rheum Dis 76:17-28. https://doi.org/10.1136/annrh eumdis-2016-209775

85. Habets KL, Huizinga TW, Toes RE (2013) Platelets and autoimmunity. Eur J Clin Invest 43:746-757. https://doi.org/10.1111/ eci.12101

86. Kehrel E, Brodde BF M (2013) State of the art in platelet function testing. Transfus Med Hemother 40:73-86. https://doi. org/10.1159/000350469

87. Lood C, Tydén H, Gullstrand B, Sturfelt G, Jönsen A, Truedsson L et al (2014) Platelet activation and anti-phospholipid antibodies collaborate in the activation of the complement system on platelets in systemic lupus erythematosus. PLoS One 9(6):e99386. https://doi.org/10.1371/journal.pone.0099386

88. Gasparyan AY, Stavropoulos-Kalinoglou A, Mikhailidis DP, Douglas KM, Kitas GD (2011) Platelet function in rheumatoid arthritis: arthritic and cardiovascular implications. Rheumatol Int 31:153-164. https://doi.org/10.1007/s00296-010-1446-x

89. Harifi G, Sibilia J (2016) Pathogenic role of platelets in rheumatoid arthritis and systemic autoimmune diseases. Perspectives and therapeutic aspects. Saudi Med J 37:354-360. https://doi. org/10.15537/smj.2016.4.14768

90. Kisacik B, Tufan A, Kalyoncu U, Karadag O, Akdogan A, Ozturk MA et al (2008) Mean platelet volume (MPV) as an inflammatory marker in ankylosing spondylitis and rheumatoid arthritis. Joint Bone Spine 75:291-294. https://doi.org/10.1016/j.jbspi n.2007.06.016

91. Boilard E, Blanco P, Nigrovic PA (2012) Platelets: active players in the pathogenesis of arthritis and SLE. Nat Rev Rheumatol 8:534-542. https://doi.org/10.1038/nrrheum.2012.118

92. Işı1k M, Şahin H, Hüseyin E (2014) New platelet indices as inflammatory parameters for patients with rheumatoid arthritis. Eur J Rheumatol 1:144-146. https://doi.org/10.5152/eurjrheuma tol.2014.140023

93. Knijff-Dutmer EA, Koerts J, Nieuwland R, Kalsbeek-Batenburg EM, van de Laar MA (2002) Elevated levels of platelet microparticles are associated with disease activity in rheumatoid arthritis. Arthritis Rheum 46:1498-1503. https://doi.org/10.1002/ art. 10312

94. Mott PJ, Lazarus AH (2013) CD44 antibodies and immune thrombocytopenia in the amelioration of murine inflammatory arthritis. PLoS One 8(6):e65805. https://doi.org/10.1371/journ al.pone. 0065805

95. Habets KL, Trouw LA, Levarht EW, Korporaal SJ, Habets PA, de Groot P et al (2015) Anti-citrullinated protein antibodies contribute to platelet activation in rheumatoid arthritis. Arthritis Res Ther 17:209. https://doi.org/10.1186/s13075-015-0665-7

96. Sokolove J, Brennan MJ, Sharpe O, Lahey LJ, Kao AH, Krishnan E et al (2013) Brief report: citrullination within the atherosclerotic plaque: a potential target for the anti-citrullinated protein antibody response in rheumatoid arthritis. Arthritis Rheum 65:1719-1724. https://doi.org/10.1002/art.37961

97. Weyrich AS, Zimmerman GA (2004) Platelets: signaling cells in the immune continuum. Trends Immunol 25:489-495. https ://doi.org/10.1016/j.it.2004.07.003

98. Vázquez-Del Mercado M, Nuñez-Atahualpa L, Figueroa-Sánchez M, Gómez-Bañuelos E, Rocha-Muñoz AD, Martín-Márquez BT et al (2015) Serum levels of anticyclic citrullinated peptide antibodies, interleukin-6, tumor necrosis factor- $\alpha$, and C-reactive protein are associated with increased carotid intima-media thickness: a cross-sectional analysis of a cohort of rheumatoid arthritis patients without cardiovascular risk factors. Biomed Res Int. 2015:342649. https://doi.org/10.1155/2015/342649
99. Verschoor A, Langer HF (2013) Crosstalk between platelets and the complement system in immune protection and disease. Thromb Haemost 110:910-919. https://doi.org/10.1160/ TH13-02-0102

100. Gerli R, Bartoloni Bocci E, Sherer Y, Vaudo G, Moscatelli S, Shoenfeld Y (2008) Association of anti-cyclic citrullinated peptide antibodies with subclinical atherosclerosis in patients with rheumatoid arthritis. Ann Rheum Dis 67:724-725. https://doi. org/10.1136/ard.2007.073718

101. Barbarroja N, Pérez-Sanchez C, Ruiz-Limon P, Castro-Villegas C, Aguirre MA, Carretero R et al (2014) Anticyclic citrullinated protein antibodies are implicated in the development of cardiovascular disease in rheumatoid arthritis. Arterioscler Thromb Vasc Biol 34:2706-2716. https://doi.org/10.1161/ATVBA HA. 114.304475

102. Boilard E, Nigrovic PA, Larabee K, Watts GF, Coblyn JS, Weinblatt ME et al (2010) Platelets amplify inflammation in arthritis via collagen-dependent microparticle production. Science 327:580-583. https://doi.org/10.1126/science.1181928

103. Kojima F, Naraba H, Sasaki Y, Beppu M, Aoki H, Kawai S (2003) Prostaglandin E2 is an enhancer of interleukin-1betainduced expression of membrane-associated prostaglandin $\mathrm{E}$ synthase in rheumatoid synovial fibroblasts. Arthritis Rheum 48:2819-2828. https://doi.org/10.1002/art.11261

104. Bartok B, Firestein GS (2010) Fibroblast-like synoviocytes: key effector cells in rheumatoid arthritis. Immunol Rev 233:233-255. https://doi.org/10.1111/j.0105-2896.2009.00859.x

105. Jüngel A, Distler O, Schulze-Horsel U, Huber LC, Ha HR, Simmen B et al (2007) Microparticles stimulate the synthesis of prostaglandin $\mathrm{E}(2)$ via induction of cyclooxygenase 2 and microsomal prostaglandin E synthase 1. Arthritis Rheum 56:3564-3574. https://doi.org/10.1002/art.22980

106. Boilard E, Larabee K, Shnayder R, Jacobs K, Farndale RW, Ware $\mathrm{J}$ et al (2011) Platelets participate in synovitis via Cox-1-dependent synthesis of prostacyclin independently of microparticle generation. J Immunol 186:4361-4366. https://doi.org/10.4049/ jimmunol.1002857

107. Giera M, Ioan-Facsinay A, Toes R, Gao F, Dalli J, Deelder AM et al (2012) Lipid and lipid mediator profiling of human synovial fluid in rheumatoid arthritis patients by means of LC-MS/ MS. Biochim Biophys Acta 1821:1415-1424. https://doi. org/10.1016/j.bbalip.2012.07.011

108. Chan MM, Moore AR (2010) Resolution of inflammation in murine autoimmune arthritis is disrupted by cyclooxygenase- 2 inhibition and restored by prostaglandin E2-mediated lipoxin A4 production. J Immunol 184:6418-6426. https://doi.org/10.4049/ jimmunol.0903816

109. Burbano C, Rojas M, Vásquez G, Castaño D. (2015) Microparticles that form immune complexes as modulatory structures in autoimmune responses. Mediators Inflamm. 2015:267590. https ://doi.org/10.1155/2015/267590

110. Lundberg K, Nijenhuis S, Vossenaar ER, Palmblad K, van Venrooij WJ, Klareskog L et al (2005) Citrullinated proteins have increased immunogenicity and arthritogenicity and their presence in arthritic joints correlates with disease severity. Arthritis Res Ther 7:R458-467. https://doi.org/10.1186/ar1697

111. Burska AN, Hunt L, Boissinot M, Strollo R, Ryan BJ, Vital E et al (2014) Autoantibodies to posttranslational modifications in rheumatoid arthritis. Mediators Inflamm 2014:492873. https:// doi.org/10.1155/2014/492873

112. Maugeri N, Rovere-Querini P, Manfredi AA (2016) Disruption of a regulatory network consisting of neutrophils and platelets fosters persisting inflammation in rheumatic diseases. Front Immunol 7:182. https://doi.org/10.3389/fimmu.2016.00182

113. Khandpur R, Carmona-Rivera C, Vivekanandan-Giri A, Gizinski A, Yalavarthi S, Knight JS et al (2013) NETs are a source of 
citrullinated autoantigens and stimulate inflammatory responses in rheumatoid arthritis. Sci Transl Med 5:178ra40. https://doi. org/10.1126/scitranslmed.3005580

114. Mauler M, Bode C, Duerschmied D (2016) Platelet serotonin modulates immune functions. Hamostaseologie 36:11-16. https ://doi.org/10.5482/HAMO-14-11-0073

115. Pattanaik D, Brown M, Postlethwaite BC, Postlethwaite AE (2015) Pathogenesis of systemic sclerosis. Front Immunol 6:272. https://doi.org/10.3389/fimmu.2015.00272

116. McCarthy EM, Moreno-Martinez D, Wilkinson FL, McHugh NJ, Bruce IN, Pauling JD et al (2017) Microparticle subpopulations are potential markers of disease progression and vascular dysfunction across a spectrum of connective tissue disease. BBA Clin 7:16-22. https://doi.org/10.1016/j.bbacli.2016.11.003

117. Ramirez GA, Franchini S, Rovere-Querini P, Sabbadini MG, Manfredi AA, Maugeri N (2012) The role of platelets in the pathogenesis of systemic sclerosis. Front Immunol 3:160. https ://doi.org/10.3389/fimmu.2012.00160

118. Silveri F, De Angelis R, Poggi A, Muti S, Bonapace G, Argentati F et al (2001) Relative roles of endothelial cell damage and platelet activation in primary Raynaud's phenomenon (RP) and RP secondary to systemic sclerosis. Scand J Rheumatol 30:290-296

119. Pamuk GE, Turgut B, Pamuk ON, Vural O, Demir M, Cakir N (2007) Increased circulating platelet-leucocyte complexes in patients with primary Raynaud's phenomenon and Raynaud's phenomenon secondary to systemic sclerosis: a comparative study. Blood Coagul Fibrinolysis 18:297-302. https://doi. org/10.1097/MBC.0b013e328010bd05

120. Postlethwaite AE, Chiang TM (2007) Platelet contributions to the pathogenesis of systemic sclerosis. Curr Opin Rheumatol 19:574-579. https://doi.org/10.1097/BOR.0b013e3282eeb3a4

121. Beretta L, Cossu M, Marchini M, Cappiello F, Artoni A, Motta $G$ et al (2008) A polymorphism in the human serotonin 5-HT2A receptor gene may protect against systemic sclerosis by reducing platelet aggregation. Arthritis Res Ther 10(5):R103. https://doi.org/10.1186/ar2495

122. Manetti M, Guiducci S, Ibba-Manneschi L, MatucciCerinic M (2010) Mechanisms in the loss of capillaries in systemic sclerosis: angiogenesis versus vasculogenesis. J Cell Mol Med 14:1241-1254. https://doi.org/10.111 1/j.1582-4934.2010.01027.x

123. Hirigoyen D, Burgos PI, Mezzano V, Duran J, Barrientos M, Saez CG et al (2015) Inhibition of angiogenesis by platelets in systemic sclerosis patients. Arthritis Res Ther 17:332. https:// doi.org/10.1186/s13075-015-0848-2

124. van Bon L, Affandi AJ, Broen J, Christmann RB, Marijnissen RJ, Stawski L et al (2014) Proteome-wide analysis and CXCL4 as a biomarker in systemic sclerosis. N Engl J Med 370:433-443. https://doi.org/10.1056/NEJMoa1114576

125. Maidhof W, Hilas O (2012) Lupus: an overview of the disease and management options. P T 37:240-249

126. Jung JH, Soh MS, Ahn YH, Um YJ, Jung JY, Suh CH et al (2016) Thrombocytopenia in systemic lupus erythematosus: clinical manifestations, treatment, and prognosis in 230 patients. Medicine (Baltimore) 95(6):e2818. https://doi. org/10.1097/MD.0000000000002818

127. Dieker J, Tel J, Pieterse E, Thielen A, Rother N, Bakker M et al (2016) Circulating apoptotic microparticles in systemic lupus erythematosus patients drive the activation of dendritic cell subsets and prime neutrophils for NETosis. Arthritis Rheumatol 68:462-472. https://doi.org/10.1002/art.39417

128. Kim KJ, Baek IW, Yoon CH, Kim WU, Cho CS (2017) Elevated levels of soluble CD40 ligand are associated with antiphospholipid antibodies in patients with systemic lupus erythematosus. Clin Exp Rheumatol 35:823-830
129. Becker-Merok A, Østli-Eilersten G, Lester S, Nossent J (2013) Circulating interferon- $\alpha 2$ levels are increased in the majority of patients with systemic lupus erythematosus and are associated with disease activity and multiple cytokine activation. Lupus 22:155-163. https://doi.org/10.1177/0961203312468964

130. Lood C, Amisten S, Gullstrand B, Jönsen A, Allhorn M, Truedsson L et al (2010) Platelet transcriptional profile and protein expression in patients with systemic lupus erythematosus: up-regulation of the type I interferon system is strongly associated with vascular disease. Blood 116:1951-1957. https ://doi.org/10.1182/blood-2010-03-274605

131. Ullal AJ, Reich CF, Clowse M, Criscione-Schreiber LG, Tochacek M, Monestier M et al (2011) Microparticles as antigenic targets of antibodies to DNA and nucleosomes in systemic lupus erythematosus. J Autoimmun 36:173-180. https ://doi.org/10.1016/j.jaut.2011.02.001

132. Nielsen CT, Østergaard O, Stener L, Iversen LV, Truedsson L, Gullstrand B et al (2012) Increased IgG on cell-derived plasma microparticles in systemic lupus erythematosus is associated with autoantibodies and complement activation. Arthritis Rheum 64:227-236. https://doi.org/10.1002/art.34381

133. Ryan BJ, Nissim A, Winyard PG (2014) Oxidative post-translational modifications and their involvement in the pathogenesis of autoimmune diseases. Redox Biol 2:715-724. https://doi. org/10.1016/j.redox.2014.05.004

134. Das UN (2010) Current and emerging strategies for the treatment and management of systemic lupus erythematosus based on molecular signatures of acute and chronic inflammation. $\mathbf{J}$ Inflamm Res 3:143-170. https://doi.org/10.2147/JIR.S9425

135. Ruiz-Irastorza G, Crowther M, Branch W, Khamashta MA (2010) Antiphospholipid syndrome. Lancet 376:1498-1509. https://doi. org/10.1016/S0140-6736(10)60709-X

136. Sanna G, Bertolaccini ML, Mameli A, Hughes GR, Khamashta MA, Mathieu A (2005) Antiphospholipid antibodies in patients with scleroderma: prevalence and clinical significance. Ann Rheum Dis 64:1795-1796. https://doi.org/10.1136/ ard.2005.038430

137. Kim KJ, Baek IW, Park KS, Kim WU, Cho CS (2017) Association between antiphospholipid antibodies and arterial thrombosis in patients with rheumatoid arthritis. Lupus 26:88-94. https://doi. org/10.1177/0961203316658557

138. Baroni G, Banzato A, Bison E, Denas G, Zoppellaro G, Pengo V (2017) The role of platelets in antiphospholipid syndrome. Platelets. 2017:1-5. https://doi.org/10.1080/09537104.2017.1280150

139. Jy W, Tiede M, Bidot CJ, Horstman LL, Jimenez JJ, Chirinos J et al (2007) Platelet activation rather than endothelial injury identifies risk of thrombosis in subjects positive for antiphospholipid antibodies. Thromb Res 121:319-325. https://doi.org/10.1016/j. thromres.2007.04.014

140. Yazici S, Yazici M, Erer B, Calik Y, Ozhan H, Ataoglu S (2010) The platelet indices in patients with rheumatoid arthritis: mean platelet volume reflects disease activity. Platelets 21:122-125. https://doi.org/10.3109/09537100903474373

141. Safak S, Uslu AU, Serdal K, Turker T, Soner S, Lutfi A (2014) Association between mean platelet volume levels and inflammation in SLE patients presented with arthritis. Afr Health Sci 14:919-924. https://doi.org/10.4314/ahs.v14i4.21

142. Delgado-García G, Galarza-Delgado D, Colunga-Pedraza I, Borjas-Almaguer OD, Mandujano-Cruz I, Benavides-Salgado $\mathrm{D}$ et al (2016) Mean platelet volume is decreased in adults with active lupus disease. Rev Bras Reumatol 56:504-508. https://doi. org/10.1016/j.rbr.2015.12.003

143. Huang ZY, Chien P, Indik ZK, Schreiber AD (2011) Human platelet Fc $\gamma$ RIIA and phagocytes in immune-complex clearance. Mol Immunol 48:691-696. https://doi.org/10.1016/j.molim m.2010.11.017 
144. Gasparyan AY, Sandoo A, Stavropoulos-Kalinoglou A, Kitas GD (2010) Mean platelet volume in patients with rheumatoid arthritis: the effect of anti-TNF- $\alpha$ therapy. Rheumatol Int 30:11251129. https://doi.org/10.1007/s00296-009-1345-1

145. Noris P, Melazzini F, Balduini CL (2016) New roles for mean platelet volume measurement in the clinical practice? Platelets 27:607-612. https://doi.org/10.1080/09537104.2016.1224828

146. Vagdatli E, Gounari E, Lazaridou E, Katsibourlia E, Tsikopoulou F, Labrianou I (2010) Platelet distribution width: a simple, practical and specific marker of activation of coagulation. Hippokratia 14:28-32

147. Harrison P, Goodall AH (2016) Studies on mean platelet volume (MPV)—new editorial policy. Platelets 27:605-606. https://doi. org/10.1080/09537104.2016.1225467

148. De Luca G, Verdoia M, Cassetti E, Schaffer A, Di Giovine G, Bertoni A et al (2013) Mean platelet volume is not associated with platelet reactivity and the extent of coronary artery disease in diabetic patients. Blood Coagul Fibrinolysis 24:619-624. https ://doi.org/10.1097/MBC.0b013e328360c75a

149. Huczek Z, Kochman J, Filipiak KJ, Horszczaruk GJ, Grabowski M, Piatkowski R et al (2005) Mean platelet volume on admission predicts impaired reperfusion and long-term mortality in acute myocardial infarction treated with primary percutaneous coronary intervention. J Am Coll Cardiol 46:284-290. https:// doi.org/10.1016/j.jacc.2005.03.065

150. Makowski M, Smorag I, Makowska J, Bissinger A, Grycewicz T, Paśnik J et al (2017) Platelet reactivity and mean platelet volume as risk markers of thrombogenesis in atrial fibrillation. Int J Cardiol 235:1-5. https://doi.org/10.1016/j.ijcard.2017.03.023

151. Chu SG, Becker RC, Berger PB, Bhatt DL, Eikelboom JW, Konkle B et al (2010) Mean platelet volume as a predictor of cardiovascular risk: a systematic review and meta-analysis. J Thromb Haemost 8:148-156. https://doi.org/10.111 1/j.1538-7836.2009.03584.x

152. Tanaka T, Narazaki M, Kishimoto T (2014) IL-6 in inflammation, immunity, and disease. Cold Spring Harb Perspect Biol 6(10):a016295. https://doi.org/10.1101/cshperspect.a016295

153. Kaplan MJ (2010) Cardiovascular complications of rheumatoid arthritis: assessment, prevention, and treatment. Rheum Dis Clin North Am 36:405-426. https://doi.org/10.1016/j.rdc.2010.02.002

154. Bendinelli P, Matteucci E, Dogliotti G, Corsi MM, Banfi G, Maroni P et al (2010) Molecular basis of anti-inflammatory action of platelet-rich plasma on human chondrocytes: mechanisms of NF-кB inhibition via HGF. J Cell Physiol 225:757-766. https://doi.org/10.1002/jcp.22274

155. Anitua E, Andia I, Ardanza B, Nurden P, Nurden AT (2004) Autologous platelets as a source of proteins for healing and tissue regeneration. Thromb Haemost 91:4-15. https://doi.org/10.1160/ TH03-07-0440

156. Lippross S, Moeller B, Haas H, Tohidnezhad M, Steubesand $\mathrm{N}$, Wruck CJ et al (2011) Intraarticular injection of plateletrich plasma reduces inflammation in a pig model of rheumatoid arthritis of the knee joint. Arthritis Rheum 63:3344-3353. https ://doi.org/10.1002/art.30547

157. Serhan CN, Savill J (2005) Resolution of inflammation: the beginning programs the end. Nat Immunol 6:1191-1197. https ://doi.org/10.1038/ni1276

158. Kapur R, Zufferey A, Boilard E, Semple JW (2015) Nouvelle cuisine: platelets served with inflammation. J Immunol 194:5579_ 5587. https://doi.org/10.4049/jimmunol.1500259 